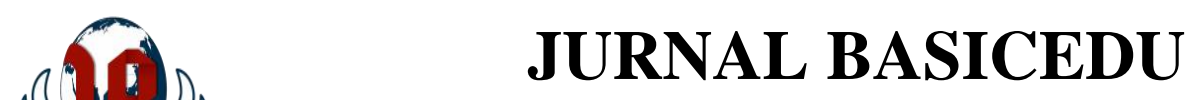

Volume 5 Nomor 5 Tahun 2021 Halaman 3050 - 3060

Research \& Learning in Elementary Education

https://jbasic.org/index.php/basicedu

PAHLAWAN

\title{
Pengembangan Media Pembelajaran Webtoon untuk Menanamkan Sikap Toleransi Siswa di Sekolah Dasar
}

\author{
Nuryanah $^{1 凶}$, Linda Zakiah $^{2}$, Fahrurrozi $^{3}$, Uswatun Hasanah ${ }^{4}$ \\ Pendidikan Guru Sekolah Dasar, Universitas Negeri Jakarta, Indonesia ${ }^{1,2,3,4}$ \\ E-mail: nuryanahnur1@gmail.com¹ ${ }^{1}$ lindazakiah@unj.ac.id ${ }^{2}$, fahrurrozi@unj.ac.id² $^{3}$, \\ uswatunhasanah@unj.ac.id ${ }^{4}$
}

\begin{abstract}
Abstrak
Media pembelajaran webtoon adalah suatu perangkat bantu yang digunakan untuk menyampaikan informasi dalam bentuk kumpulan gambar komik yang dipublikasikan secara digital dalam bentuk aplikasi yang diunduh atau web dengan menggunakan ponsel, ipad, laptop, komputer atau alat elektronik yang sejenisnya untuk menanamkan sikap toleransi siswa. Tujuan pengembangan penelitian ini untuk menghasilkan sebuah produk berupa media pembelajaran dengan menggunakan aplikasi webtoon tentang keragaman di Indonesia dalam muatan pembelajaran PPKN untuk siswa kelas IV sekolah dasar. Metode penelitian ini menggunakan jenis penelitian pengembangan (research and development) dengan model pengembangan ADDIE dari Dick and Peck. Tahapan model pengembangan ini terdiri dari analisis, desain, pengembangan, implementasi dan evaluasi. Teknik pengumpulan data melalui kuesioner/angket. Teknik analisis data menggunakan skala likert. Adapun tahap validasi ahli, yaitu validasi oleh ahli media, validasi oleh ahli materi dan validasi media yang dilakukan oleh siswa. Hasil ini menunjukkan bahwa nilai validasi oleh ahli media, ahli materi dan respon siswa memperoleh nilai lebih dari $91 \%$ sehingga pengembangan media pembelajaran webtoon dikategorikan sangat layak dengan revisi.
\end{abstract}

Kata Kunci: Pengembangan, Webtoon, Media Pembelajaran.

\begin{abstract}
Webtoon learning media is a tool that is used to convey information in the form of a collection of comic images published digitally in the form of a downloaded application or web by using a cellphone, iPad, laptop, computer, or similar electronic device to instill a tolerance attitude in students. The purpose of developing this research is to produce a product in the form of learning media using a webtoon application about diversity in Indonesia in PPKN learning content for fourth-grade elementary school students. This research method uses research and development with the ADDIE development model from Dick and Peck. The stages of this development model consist of analysis, design, development, implementation, and evaluation. The technique of collecting data is through a questionnairelquestionnaire. The data analysis technique used a Likert scale. The expert validation stage, namely validation by media experts, validation by material experts and media validation carried out by students. These results indicate that the value of validation by media experts, material experts, and students response scores more than $91 \%$ so that the development of webtoon learning media is categorized as feasible with revision.
\end{abstract}

Keywords: Development, Webtoon, Learning Media.

Copyright (c) 2021 Nuryanah, Linda Zakiah, Fahrurrozi, Uswatun Hasanah

Corresponding author :

Email : nuryanahnur1@gmail.com

DOI $\quad$ : https://doi.org/10.31004/basicedu.v5i5.1244

ISSN 2580-3735 (Media Cetak)

ISSN 2580-1147 (Media Online)

Jurnal Basicedu Vol 5 No 5 Tahun 2021

p-ISSN 2580-3735 e-ISSN 2580-1147 
3051 Pengembangan Media Pembelajaran Webtoon untuk Menanamkan Sikap Toleransi Siswa di Sekolah Dasar - Nuryanah, Linda Zakiah, Fahrurrozi, Uswatun Hasanah

DOI: https://doi.org/10.31004/basicedu.v5i5.1244

\section{PENDAHULUAN}

Saat ini di Indonesia dan hampir di seluruh dunia terpapar virus Covid-19 yang membuat pembelajaran tatap muka menjadi terhambat. Menurut Kemenkes RI (RI, 2020) Covid-19 merupakan corona virus jenis baru yang pertama kali ditemukan di Wuhan, China pada Desember 2019 yang menyebabkan gejala batuk, flu, demam dan menyerang pernapasan serta penyebaran virus ini sangat cepat. Kondisi ini membuat kegiatan pembelajaran dialihkan menjadi pembelajaran jarak jauh. Dengan adanya pembelajaran jarak jauh ini, guru tidak dapat memantau sikap siswa, perkembangan siswa, dan keaktifan siswa secara langsung.

Padahal kegiatan pembelajaran kurikulum 2013 ini menekan kepada sikap individu siswa khususnya pada muatan pembelajaran PPKN. Menurut (Angraini, n.d.) pendidikan kewarganegaraan merupakan muatan pembelajaran yang digunakan untuk mengembangkan suatu karakter yang bernilai dan bermoral yang sesuai dengan budaya bangsa Indonesia yang diharapkan mampu mewujudukan dan mengimplementasikan karakter tersebut sebagai perilaku dalam kehidupan sehari-hari. Hal ini selaras dengan program yang dicanangkan oleh pemerintah, yakni Pendidikan Penguatan Karakter (PPK). Menurut (Mendikbud, 2017) Pendidikan Penguatan Karakter (PKK) merupakan suatu roh utama pendidikan dan fondasi agar untuk mendukung dan mendorong agar pendidikan nasional kembali memperhatikan olah hati (spiritual dan etnik), olah rasa (estetik), dan olah raga (kinestetik) sehingga nilai karakter utama Pancasila dapat diimplementasikan. Apalagi Indonesia termasuk negara yang majemuk dengan keanekaragaman suku, ras, agama, bahasa dan budaya yang mengharuskan setiap individu bangsa memiliki sikap toleransi.

Pada kenyataannya sikap toleransi di Indonesia cukup memperihatinkan. Berdasarkan (Tim Wahid Foundation \& Lembaga Survei Indonesia, 2018) menyatakan bahwa warga negara Indonesia masih cenderung memiliki sikap tidak toleransi antar sesama. Hal ini dibuktikan dalam laporannya yang memaparkan data, yaitu kelompok yang tidak menyukai LGBT sebesar 26\%, komunis sebesar 16,7\%, Yahudi sebesar 10,6\%, Kristen 2,2\%, Syi'ah sebesar 1,3\%, Wahhabi sebesar 0,5\%, Budha sebesar 0,4\%, dan Tionghoa sebesar 0,4\%. Sedangkan yang tidak masalah dengan kelompok tersebut sebesar 38,7\%. Data tersebut jika dikalkulasikan bahwa sebanyak $61,7 \%$ tidak menyukai dan memiliki masalah dengan kelompok tertentu.

Adapun cara menanamkan sikap toleransi siswa dengan mengembangkan media pembelajaran. Media pembelajaran merupakan salah satu perangkat atau alat yang dapat memudahkan proses pembelajaran karena memiliki manfaat yang efektif sebagai penyalur suatu pesan atau infromasi. Serupa dengan pernyataan yang dikemukakan oleh (Kustiawan, 2016) bahwa media pembelajaran merupakan pengantar atau penyalur untuk menyampaikan informasi atau pesan dari komunikator kepada komunikan. Hal ini sejalan dengan pendapat (Tafonao, 2018) media pembelajaran merupakan alat bantu yang dapat merangsang perhatian, minat, pikiran, dan perasaan pembelajar atau kemampuan pembelajar sehingga dapat memotivasi dalam kegiatan pembelajaran. Dari pernyataan kedua ahli bahwa media pembelajaran dapat merangsang dalam kegiatan pembelajaran.

Media pembelajaran memiliki beberapa jenis. Seperti yang dikemukakan oleh Rudy Brets dalam (Ekayani, 2017) mengelompokan 7 jenis media, yaitu (1) media cetak. Media cetak terdiri dari bahan ajar mandiri, buku, modul dan sejenisnya; (2) media Audio. Media audio terdiri dari pita audio, radio, dan telepon; (3) Media visual diam. Media visual diam terdiri dari slide bisu, halaman cetak/non cetak, foto, gambar, dan sejenisnya; (4) media visual bergerak. Media visual bergerak terdiri dari film bisu; (5) audio semi gerak. Audio semi gerak seperti tulisan jauh yang bersuara; (6) media audio visual diam. Media audio visual diam terdiri dari halaman suara dan film rangkaian suara; (7) media audio visual gerak. Media audio visual gerak terdiri dari televisi, film, video, dan sejenisnya. Sedangkan menurut Nana Sudjana dalam (Rohani, 2019) mengelompokkan media menjadi dua, yaitu media dua dimensi dan media tiga dimensi. Media dua dimensi seperti media grafis yang terdiri dari kartun, komik, grafik, foto dan sejenisnya. Media tiga dimensi seperti 
3052 Pengembangan Media Pembelajaran Webtoon untuk Menanamkan Sikap Toleransi Siswa di Sekolah Dasar - Nuryanah, Linda Zakiah, Fahrurrozi, Uswatun Hasanah

DOI: https://doi.org/10.31004/basicedu.v5i5.1244

mockup, diorama dan sejenisnya. Nana Sudjana menyatakan bahwa media terdiri dari media dua dimensi dan tiga dimensi.

Berdasarkan klasifikasi media pembelajaran tersebut, media pembelajaran yang paling cocok digunakan untuk saat ini adalah media grafis, yaitu webtoon. Menurut Rizka dalam (Siwi et al., 2018) bahwa webtoon merupakan kepanjangan dari website dan Cartoon (kartun) serta berisi kumpulan gambar-gambar seperti komik yang dipublikasikan secara digital melalui web serta dapat diakses dengan mudah melalui smartphone android/ios, laptop, tablet dan lainnya dengan syarat harus terhubung data internet. Pernyataan Rizka menyatakan bahwa webtoon singkatan dari website dan cartoon dan kumpulan berupa gambar dengan alur cerita di dalamnya. Sejalan dengan (Hamidah, 2020) webtoon dapat digunakan oleh guru sebagai pendukung pembelajaran dengan suasana baru, yakni komik digital berbasis web untuk menambah pengetahuan dan mengimplemetasikan yang ada pada cerita webtoon tersebut. Selain itu, media pembelajaran webtoon cocok untuk usia anak sekolah dasar. Pasalnya webtoon menyajikan gambar-gambar lucu berwarna-warni dan pengambarannya bersifat konkret. Seperti pernyataan (Wahyu Nuning B, 2016) yang menyatakan bahwa perkembangan kognitif anak di usia 7 sampai 12 tahun yang masih duduk di sekolah dasar mampu memiliki karakteristik berpikir rasional, memahami suatu konsep, mengklasifikasikan suatu objek serta mampu memecahkan masalah dengan konkret.

Berdasarkan artikel yang sudah ada sebelumnya yaitu, pengembangan model pembelajaran menulis teks cerita fantasi berbasis media webtoon oleh Andi Aqzani Ramadhani dan Andi Fatimah Yunus dan pengembangan webtoon untuk pembelajaran IPS (ekonomi) di SMP oleh Fauzana Alfiani, Tri Kurnawati serta Menik Kurnia Siwi. Bahwa berdasarkan penilaian oleh ahli dan praktisi terhadap model pembelajaran menunjukkan kategori layak. Oleh karena itu, peneliti tertarik untuk melakukan penelitian hal serupa tetapi pada variable yang berbeda dengan judul pengembangan media webtoon tentang keragaman di Indonesia untuk siswa kelas IV sekolah dasar.

\section{METODE PENELITIAN}

Penelitian ini menggunakan metode penelitian dan pengembangan (Research and Development). Metode penelitian dan pengembangan (Research and Development) merupakan suatu cara ilmiah dengan langkah meneliti, merancang, memperoduksi dan menguji kelayakan sebuah produk (Sugiyono, 2019). Penelitian Pengembangan ini juga berlandasan pendidikan (Education Research \& Development) yang memiliki tujuan untuk menghasilkan sebuah produk berupa media pembelajaran dengan menggunakan aplikasi webtoon tentang berbagai bentuk keragaman suku bangsa, sosial dan budaya di Indonesia di dalam muatan pembelajaran PPKN untuk kelas IV sekolah dasar serta melalui proses pengembangan dan validasi produk. Model pengembangan media pembelajaran menggunakan model pengembangan ADDIE. Menurut Dick dan Carry dalam (Setiadi et al., 2018) menyatakan pendapatnya bahwa model penelitian pengembangan dikelompokkan menjadi lima tahap diantaranya yaitu, analisis, desain, pengembangan, implementasi, serta evaluasi.

Teknik pengumpulan data dalam penelitian pengembangan ini mengunakan kuisioner atau angket. Sugiyono dalam (Alfiani et al., 2018) menyatakan pendapatnya bahwa kuisioner adalah teknik pengumpulan data sebagai wadah pertanyaan ataupun pernyataan kepada responden untuk dijawab. Kuisioner ini digunakan untuk mencari informasi yang dibutuhkan dari responden dalam instrument pengumpulan data. Kuisioner ini berisi instrumen untuk melihat pendapat ahli atau validator tentang kelayakan media pembelajaran webtoon yang dikembangkan. Adapun Instrumen yang digunakan dalam penelitian pengembangan ini adalah (1) lembar instrumen validasi penilaian ahli media, (2) Lembar instrumen validasi penilaian ahli materi, (3) lembar instrumen validasi penilaian respon siswa. Analisis data ini yang mengukur kelayakan media webtoon sehingga dapat mengetahui nilai setiap aspeknya. 
3053 Pengembangan Media Pembelajaran Webtoon untuk Menanamkan Sikap Toleransi Siswa di Sekolah Dasar - Nuryanah, Linda Zakiah, Fahrurrozi, Uswatun Hasanah

DOI: https://doi.org/10.31004/basicedu.v5i5.1244

Teknik analisis data yang digunakan dalam penelitian ini, yakni skala likert yang diperoleh dari data yang dianalisis, dideskripsikan, dan disimpulkan berdasarkan kualifikasi kriteria validitas media pembelajaran untuk menentukan kriteria validitasi produk webtoon yang dikembangkan. Langkah selanjutnya mengukur kelayakan media pembelajaran dengan uraian, yakni:

Pemberian skor yang dilakukan oleh ahli media, ahli materi dan respon siswa dengan mengkategorikan sangat baik (5), baik (4), cukup baik (3), kurang (2) dan sangat kurang baik (1). Kemudian, memberikan penilaian validasi dengan rumus:

$$
\bar{x}=\frac{\Sigma x}{n}
$$

Keterangan:

$\bar{x}:$ rata-rata

$\Sigma x \quad$ : skor total

$n:$ jumlah

Lalu, berdasarkan rumus diatas diubah menjadi rumus persentase di bawah ini:

$$
\text { Hasil }=\frac{\text { Total skor yang diperoleh }}{\text { Skor maksimal }} \times 100 \%
$$

Setelah itu, mencocokkan rata-rata kelayakan media pembelajaran menurut Arikunto dalam (Ernawati, 2017), yaitu:

Tabel 1: Kategori kelayakan media pembelajaran

\begin{tabular}{lll}
\hline No. & Skor dalam persen $\mathbf{( \% )}$ & Kategori \\
\hline 1. & $<21 \%$ & Sangat tidak layak \\
\hline 2. & $21-40 \%$ & Tidak layak \\
\hline 3. & $41-60 \%$ & Cukup layak \\
\hline 4. & $61-90 \%$ & Layak \\
\hline 5. & $91-100 \%$ & Sangat Layak \\
\hline
\end{tabular}

\section{HASIL DAN PEMBAHASAN}

Hasil yang diperoleh dari penelitian dan pengembangan ini berupa media pembelajaran webtoon untuk menanamkan sikap toleransi siswa kelas IV dengan menggunakan tahapan model pengembangan ADDIE dari Dick and Carry. Tahap ADDIE ini terdiri dari tahap analisis (analysis), desain (design), pengembangan (development), implementasi (implementation) serta evaluasi (evaluation)

\section{Tahap Analisis}

Tahap analisis merupakan tahapan dalam mengumpulkan berbagai sumber-sumber dan informasi sebelum menghasilkan suatu produk pengembangan, dalam penelitian pengembangan ini produk yang akan dihasilkan ialah media pembelajaran webtoon. Pengumpulan sumber-sumber dan informasi ini, yaitu analisis kebutuhan yang dibutuhkan dalam mengembangkan produk. Analisis kebutuhan memiliki tujuan, yaitu untuk mengindetifikasi produk pengembangan dengan tujuan sasaran dalam proses pembelajaran yang bermakna, efektif dan efesien.

Berdasarkan artikel (Asriani et al., 2017) dalam melakukan uji coba lapangan menyatakan bahwa siswa kelas IV di SD Negeri Pahlawan di Kecamatan Tawang, Kota Tasikmalaya dengan rentang usia 10-11 tahun, siswa laki-laki sebanyak 16 dan siswa perempuan sebanyak 14 sehingga total siswa sejumlah 30. Sebagaian besar terdiri dari suku sunda dengan status ekonomi dan sosial yang berbeda. Menurut guru di kelas tersebut, pada saat kegiatan pembelajaran siswa dengan siswa lainnya sulit untuk diajak berkerjasama serta sikap toleransi masih kurang.

Dari pernyataan di atas, membuat peneliti tertarik untuk mengembangkan media pembelajaran dengan tujuan dapat meningkatkan sikap toleransi siswa. Media yang akan peneliti kembangkan, yakni media 
3054 Pengembangan Media Pembelajaran Webtoon untuk Menanamkan Sikap Toleransi Siswa di Sekolah Dasar - Nuryanah, Linda Zakiah, Fahrurrozi, Uswatun Hasanah

DOI: https://doi.org/10.31004/basicedu.v5i5.1244

webtoon. Karena webtoon merupakan kumpulan gambar menarik dan berwarna warni serta ilustrasi yang disajikan berdasarkan kehidupan sehari-hari sehingga mudah dipahami. Dari gambar ilustrasi tersebut siswa dapat memahami amanat pesan yang disampaikan baik secara tersurat maupun tersirat.

\section{Tahap Desain}

Tahap desain dilakukan agar memudahkan peneliti dalam mendesain webtoon yang akan dikembangkan. Adapun tahap desain sebagai berikut:

Proses dalam membuat produk pengembangan webtoon diperlukan tahapan mengumpulkan data. Hal yang diperlukan dalam mengembangkan produk pengembangan webtoon yaitu yang sudah ditentukan dalam tahap analisis. Setelah itu menentukan Storyboard. Storyboard merupakan alur cerita yang akan dirancang oleh peneliti sehingga memudahkan peneliti dalam mendeskripsikan ide atau alur cerita. Storyboard juga menunjukkan langkah-langkah dalam pembuatan suatu produk yang akan dihasilkan. Storyboard bertujuan untuk menerangkan atau menjelaskan langkah-langkah kerja produk yang akan dihasilkan Sehingga memudahkan dalam proses pembuatan webtoon.

\section{Tahap Pengembangan}

Pada tahap pengembangan ini merupakan tahapan dalam mewujudkan apa yang telah dirancang dalam tahap desain sehingga menjadi suatu produk. Hasil produk ini yang akan diujicobakan. Adapun tahapan pengembangan dapat diuraikan sebagai berikut:

Pertama, yaitu storyline. Storyline merupakan garis cerita dengan membuat alur cerita di dalam webtoon. Storyline ini yang menunjukkan latar cerita agar mudah dimengerti oleh pembaca khususnya siswa kelas IV Sekolah Dasar. Kedua, yaitu ilustrasi. Ilustrasi merupakan suatu gambar yang bertujuan untuk menjelaskan atau menerangkan kejadian di dalam gambar tersebut. Selain itu ilustrasi sebagai pendukung alur cerita serta penghias secara konkret sehingga mudah dipahami. Tidak hanya itu saja, ilustrasi merupakan daya tarik yang kuat untuk memacu siswa karena visualisasinya dalam bentuk nyata, berwarna dan bervariasi. Ketiga, yaitu emphasis dalam webtoon. Emphasis dalam webtoon merupakan satu panel dalam webtoon atau suatu adegan yang terfokus dan menarik sehingga memberikan perhatian yang tertuju dalam suatu adegan atau satu panel dalam webtoon tersebut. Keempat, yaitu karakter. Karaktek adalah suatu tokoh dalam cerita untuk menyempurnakan alur cerita dan ilustrasi yang sudah disebutkan sebelumnya. Karakter ini berguna untuk menarik perhatian pembaca sehingga ikut terhanyut dalam cerita tersebut. Adapun langkah pertama dalam membuat karakter, yaitu seperti apa karakter tersebut, perbedaan diantara karakter-karakter, dan peran karakter dalam cerita.

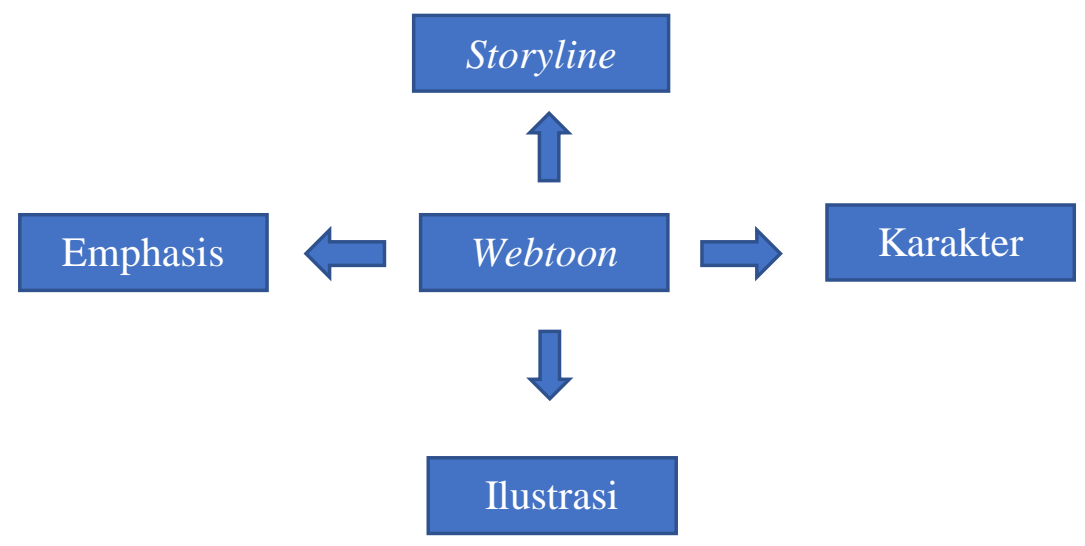

Gambar 1: Proses Pembuatan Pengembangan Media Webtoon

Media pembelajaran webtoon berisi storyline, ilustrasi, emphasis, dan karakter. Lalu, setiap panel berisi nomor halaman agar memudahkan pembaca memahami alur cerita menjadi runtut. Adapun tampilan webtoon sebagai berikut: 


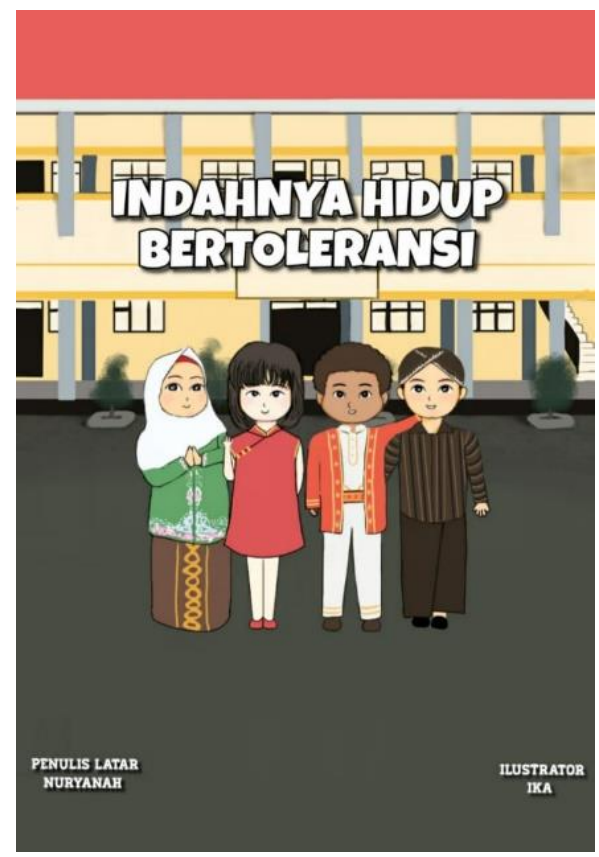

Gambar 2: Menampilakan Cover Webtoon

Pada tampilan cover media pembelajaran webtoon, terdapat background sekolah dengan tembok berwarna cream, sisi jendela sekolah tersebut berwarna hitam, tiang sekolah berwarna abu-abu, serta atap sekolah yang berwarna merah kecoklatan. Lalu, di lantai pertama sekolah terdapat pepohonan. Kemudian, terdapat anak siswa sekolah dasar berjumlah 4 orang dengan memakai pakaian adat daerahnya masingmasing. Di mana seorang anak gadis menggunakan kerudung menampilkan pakaian tradisional dari Jakarta, seorang anak gadis china menggunakan pakaian tradisional khas Tiongkok, seorang anak laki-laki berambut kriting menggunakan pakaian tradisional dari Ambon, dan terakhir seorang anak laki-laki menggunakan pakaian jawa dengan blankon yang menjadi ciri khasnya.
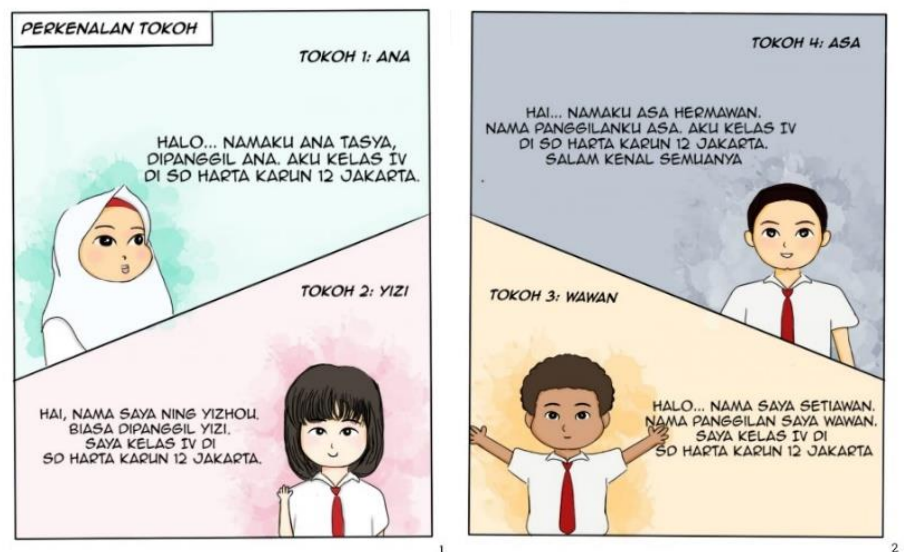

Gambar 3: Menampilkan Karakter Webtoon

Pada halaman 1 dan 2 dalam media pembelajaran webtoon terdapat pengenalan tokoh utama yang terlibat. Tokoh-tokoh yaitu (1) Seorang anak gadis menggunakan kerudung bernama Anna; (2) Seorang anak gadis china bernama Yizi; (3) Seorang anak laki-laki dengan rambut keriting bernama Wawan, dan (3) Seorang anak laki-laki yang terakhir bernama Asa. Mereka siswa kelas IV di Sekolah Dasar Harta Karun 12 Jakarta. 


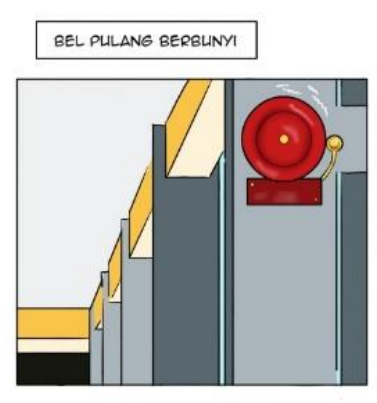

\section{Gambar 4: Menampilkan Emphasis Webtoon}

Pada halaman 6 dalam media pembelajaran webtoon terdapat emphasis. Emphasis merupakan suatu penekanan kalimat terhadap suatu objek. Hal ini terlihat pada kalimat menunjukkan latar yang menyatakan "Bel pulang berbunyi" dengan objek gambar bel sekolah. Dengan demikian, halaman 6 yang merujuk pada penekanan kalimat dan objek merupakan emphasis.

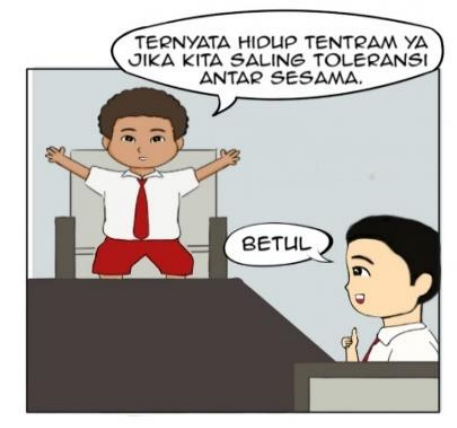

Gambar 5: Menampilkan Halaman akhir webtoon

Pada halaman terakhir dalam media pembelajaran webtoon terdapat latar belakang di ruang tamu dan dua tokoh utama laki-laki bernama Asa dan Wawan. Wawan menyatakan bahwa hidup saling berdampingan dan saling toleransi itu sungguh tentram. Hal tersebut juga disetujui oleh Asa.

\section{Tahap Implementasi}

Tahap implementasi adalah tahapan mengenai kelayakan media pembelajaran. Pada tahap ini, pertama melakukan penilaian validasi media yang dilakukan oleh ahli media dan validasi materi yang dilakukan oleh ahli materi. Setelah itu, penilaian validasi media dilakukan oleh siswa kelas IV sekolah dasar. Uji coba dilakukan dalam one to one sebanyak 3 siswa.

Hasil validasi media dihitung dan dianalisis menggunakan teknik analisis data skala likert sehingga diperoleh data sebagai berikut:

Tabel 2: Hasil penilaian validasi ahli media

\begin{tabular}{ll}
\hline $\begin{array}{l}\text { Indikator } \\
\text { Penilaian }\end{array}$ & \multicolumn{1}{c}{ Butir Penilaian } \\
\hline Tampilan & Tata letak teks dan gambar sudah sesuai \\
\cline { 2 - 2 } Media & Pilihan Latar belakang sudah sesuai \\
\hline
\end{tabular}



Dasar - Nuryanah, Linda Zakiah, Fahrurrozi, Uswatun Hasanah

DOI: https://doi.org/10.31004/basicedu.v5i5.1244

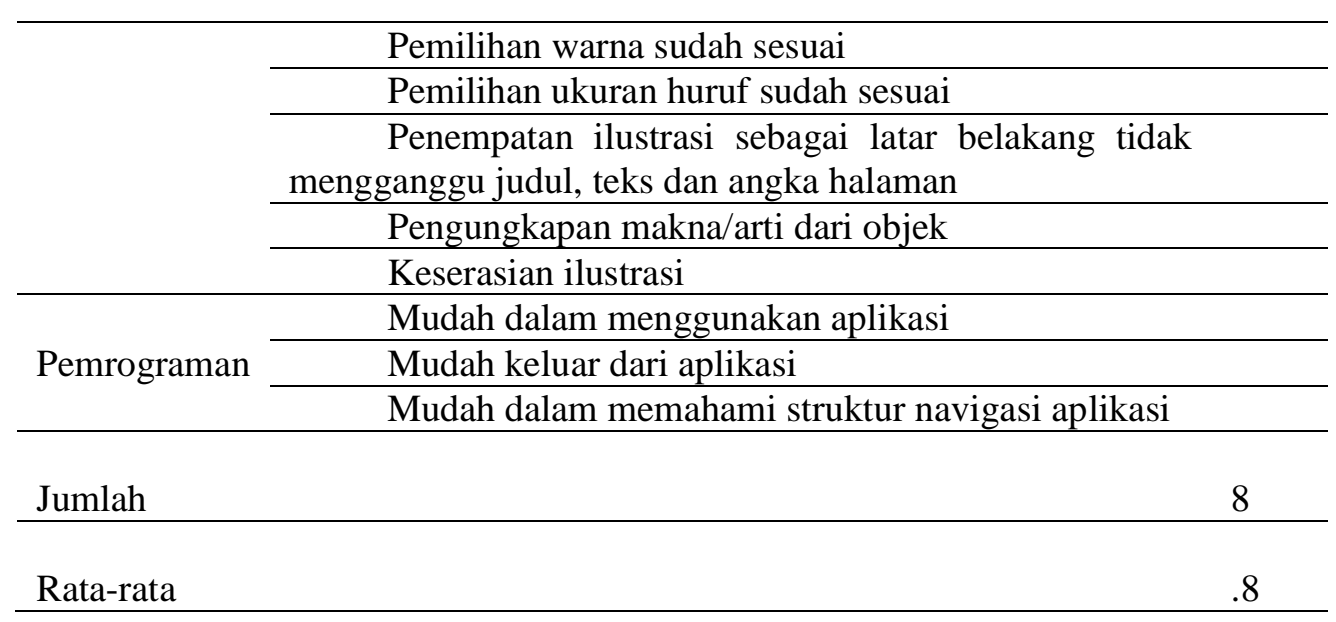

Dari tabel di atas memiliki indikator penilaian yang berjumlah 2 aspek dengan 10 butir penilaian. Adapun perhitungan skor berjumlah 1 sampai 5 dengan kategori sangat kurang bernilai 1, kurang bernilai 2, cukup bernilai 3, baik bernilai 4 dan sangat baik bernilai 5 . Rata-rata penilaian validasi ahli media bernilai 4.80 sehingga media pembelajaran webtoon dapat dihitung dalam persentase sebagai berikut:

$$
\frac{48}{50} \times 100 \%=96 \%
$$

Jadi, skor di atas menyatakan bahwa media pembelajaran berdasarkan ahli media dikategorikan sangat layak dengan skor yang diperoleh $96 \%$.

Selanjutnya, hasil validasi materi dihitung dan dianalisis menggunakan teknik analisis data skala likert sehingga diperoleh data sebagai berikut:

Tabel 3: Hasil penilaian validasi ahli materi

\begin{tabular}{|c|c|c|}
\hline Aspek & Indikator & Nilai \\
\hline \multirow{3}{*}{$\begin{array}{l}\text { Kesesuaian materi } \\
\text { dengan KD }\end{array}$} & Kelengkapan materi yang ditinjau dari KD & 4 \\
\hline & Keluasan materi ditinjau dari KD & 5 \\
\hline & Kedalaman materi ditinjau dari KD & 5 \\
\hline \multirow{3}{*}{$\begin{array}{l}\text { Keakuratan } \\
\text { materi }\end{array}$} & Keakuratan konsep & 4 \\
\hline & Keakuratan masalah dan contoh & 5 \\
\hline & Keakuratan gambar dan ilustrasi & 5 \\
\hline \multirow{2}{*}{$\begin{array}{l}\text { Kemuktahiran } \\
\text { materi }\end{array}$} & $\begin{array}{l}\text { Penggunaan ilustrasi masalah yang berkaitan } \\
\text { dengan kehidupan sehari-hari }\end{array}$ & 5 \\
\hline & $\begin{array}{l}\text { Penggunaan gambar dan ilustrasi yang } \\
\text { berkaitan dengan kehidupan sehari-hari }\end{array}$ & 5 \\
\hline $\begin{array}{l}\text { Mendorong } \\
\text { keingintahuan }\end{array}$ & Mendorong rasa ingin tahu & 4 \\
\hline Jumlah & & 42 \\
\hline Rata-Rata & & 4.666667 \\
\hline
\end{tabular}

Dari tabel di atas memiliki indikator penilaian yang berjumlah 4 aspek dengan 9 butir penilaian. Adapun perhitungan skor berjumlah 1 sampai 5 dengan kategori sangat kurang bernilai 1, kurang bernilai 2, cukup bernilai 3 , baik bernilai 4 dan sangat baik bernilai 5 . Rata-rata penilaian validasi ahli materi bernilai 4.66 sehingga media pembelajaran webtoon dapat dihitung dalam persentase sebagai berikut:

$$
\frac{42}{45} \times 100 \%=93 \%
$$

Jadi, skor di atas menyatakan bahwa media pembelajaran berdasarkan ahli materi dikategorikan sangat layak dengan skor yang diperoleh $93 \%$. 
Terakhir, hasil validasi media oleh siswa dengan uji coba one to one sebanyak 3 orang. lalu, dihitung dan dianalisis menggunakan teknik analisis data skala likert sehingga diperoleh data sebagai berikut:

Tabel 4: Hasil penilaian validasi media oleh siswa

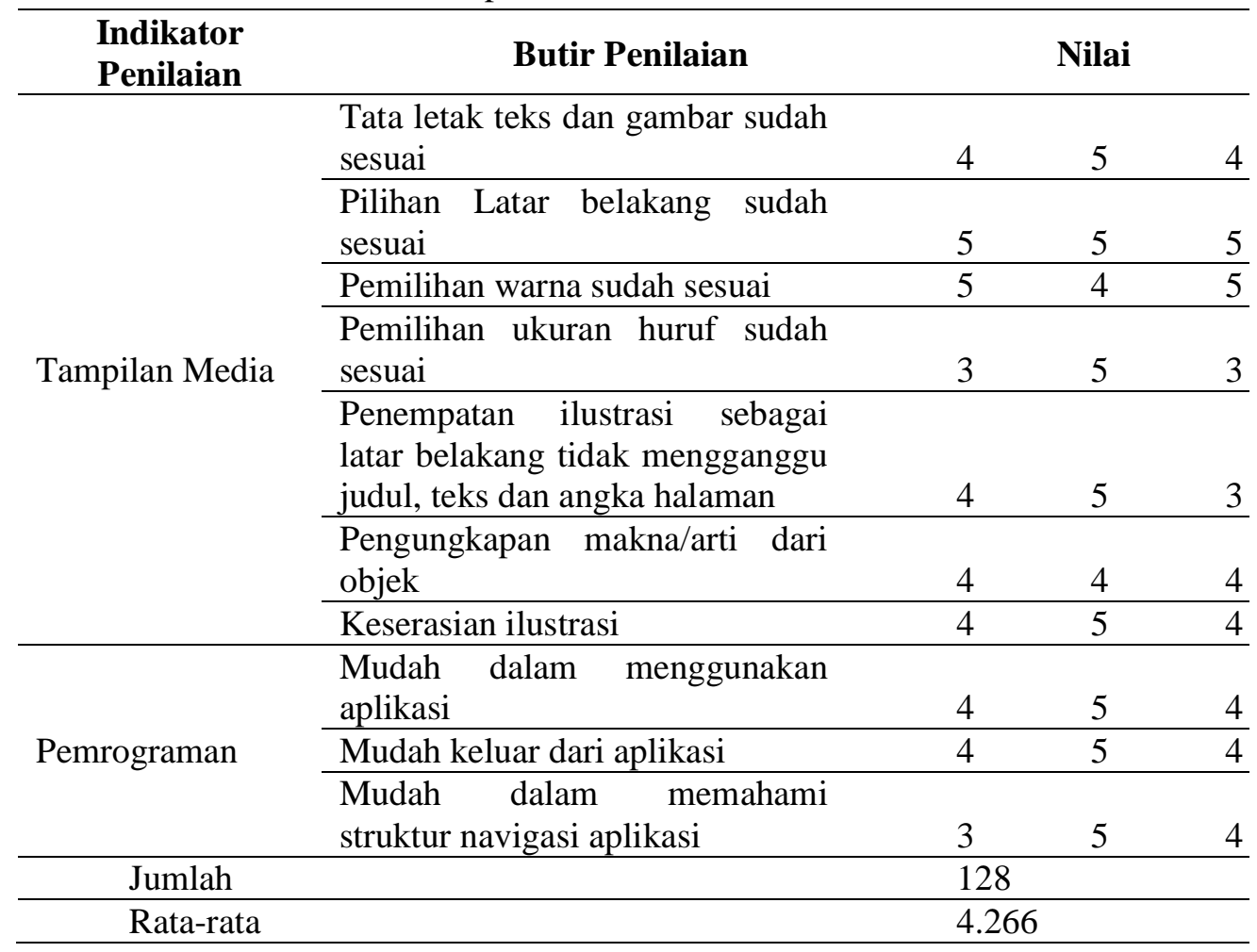

Dari tabel di atas memiliki indikator penilaian yang berjumlah 2 aspek dengan 10 butir penilaian. Adapun perhitungan skor berjumlah 1 sampai 5 dengan kategori sangat kurang bernilai 1, kurang bernilai 2, cukup bernilai 3, baik bernilai 4 dan sangat baik bernilai 5. Rata-rata penilaian validasi respon siswa bernilai 4.266 sehingga media pembelajaran webtoon dapat dihitung dalam persentase sebagai berikut:

$$
\frac{128}{150} \times 100 \%=85,33 \%
$$

Jadi, skor di atas menyatakan bahwa media pembelajaran berdasarkan respon siswa dikategorikan layak dengan skor yang diperoleh $85,33 \%$.

Dengan demikian, ketiga penilaian validasi di atas jika dikalkulasikan memperoleh skor 91,44\%. Skor tersebut merupakan kategori sangat layak. Sehingga media pembelajaran webtoon secara keseluruhan memperoleh $91.44 \%$ dan dengan kategori sangat layak.

\section{Tahap Evaluasi}

Tahap Evaluasi merupakan tahap yang harus diperbaiki dalam pengembangan produk seperti dalam media pembelajaran webtoon komponen apa saja yang harus diperbaiki sehingga menjadi media pembelajaran yang bermakna, efektif dan efesien. Adapun media pembelajaran webtoon disimpulkan layak dengan revisi karena rata-rata validasi oleh ahli media, ahli materi dan siswa kelas 4 memperoleh nilai 91,44\%. Kritik dan saran yang diperoleh, yaitu dengan menambahkan panel yang kurang serta mengkaji bahasa apakah sudah sesuai dengan anak sekolah dasar.

Hasil validasi menyimpulkan bahwa penerapan pembelajaran media webtoon memperoleh kelayakan yang dapat digunakan. Hal ini didukung oleh hasil penelitian sebelumnya, karena media webtoon ini terdiri dari storyline, ilustrasi, emphasis dan karakter yang terjadi di dalam kehidupan sehari-hari. Lalu, melakukan validasi oleh ahli media, ahli materi dan siswa sehingga memperoleh nilai 91,44\% yang dikategorikan sangat 
layak. Penggunaan media pembelajaran webtoon layak digunakan dalam pembelajaran tergantung pada peran aktif siswa.

\section{KESIMPULAN}

Penelitian pengembangan ini, yaitu hasil dari media pembelajaran webtoon tentang keragaman di Indonesia pada muatan pembelajaran PPKn untuk menanamkan sikap toleransi. Adapun tahap yang digunakan menggunakan model ADDIE, yakni analisis (analysis), desain (design), pengembangan (development), implementasi (implementation), dan evaluasi (evaluation). Dari lima tahapan tersebut dan melalui penilaian validasi ahli media, ahli, materi serta respon siswa media pembelajaran webtoon memperoleh hasil 91,44\% yang dikategorikan sangat layak.

\section{UCAPAN TERIMA KASIH}

Penulis mengucapkan terima kasih kepada semua pihak yang terlibat dalam membantu penelitian dan penulisan ini. Terima kasih penulis ucapkan kepada:

Tuhan Yang Maha Esa karena selalu diberikan kesehatan sehingga dapat menyelesaikan ini. Ibu Linda Zakiah, M.Pd., Bapak Prof. Dr. Fahrurrozi, M.Pd., dan Ibu Uswatun Hasanah, M.Pd., selaku dosen pembimbing utama yang memberikan kritik, saran dan bimbingan.

\section{DAFTAR PUSTAKA}

Alfiani, F., Kurniawati, T., \& Siwi, M. K. (2018). Pengembangan Webtoon Untuk Pembelajaran Ips (Ekonomi) Di Smp. Jurnal Ecogen, 1(2), 439. Https://Doi.Org/10.24036/Jmpe.V1i2.4766

Angraini, R. (N.D.). Karakteristik Media Yang Tepat Dalam Pembelajaran Pendidikan Kewarganegaraan Sebagai Pendidikan Nilai. 14-24.

Asriani, P., Sa'dijah, C., \& Akbar, S. (2017). Bahan Ajar Berbasis Pendidikan Karakter Untuk. Jurnal Pendidikan: Teori, Penelitian, Dan Pengembangan, 2(11), 1456-1468.

Ekayani, P. (2017). (2017). Pentingnya Penggunaan Media. March. Https://Www.Researchgate.Net/Publication/315105651

Ernawati, I. (2017). Uji Kelayakan Media Pembelajaran Interaktif Pada Mata Pelajaran Administrasi Server. Elinvo (Electronics, Informatics, And Vocational Education), 2(2), 204-210. Https://Doi.Org/10.21831/Elinvo.V2i2.17315

Hamidah, A. F. S. P. D. U. S. (2020). Bahan Ajar Berbasis Webtoon Dengan Model Mind Mapping Untuk Meningkatkan Pemahaman Konsep Pada Materi Dasar Desain Grafis. Jurnal Penelitian Pendidikan Dan Pembelajaran, 01 .

Kustiawan, U. (2016). Pengembangan Media Pembelajaran Anak Usia Dini (1st Ed.). Gunung Samudra.

Mendikbud, T. (2017). Penguatan Pendidikan Karakter Jadi Pintu Masuk Pembenahan Pendidikan Nasional. Https://Www.Kemdikbud.Go.Id/Main/Blog/2017/07/Penguatan-Pendidikan-Karakter-Jadi-Pintu-MasukPembenahan-Pendidikan-Nasional

RI, K. (2020). Kesiapansiaga Menghadapi Infeksi Covid-19. Kemkes.Go.Id/Folder/View/FullContent/Structure-Faq.Html

Rohani. (2019). Diktat Media Pembelajaran. Fakultas Ilmu Tarbiyah Dan Keguruan Universitas Islam Negeri Sumatera Utara, 95.

Setiadi, A., Yuliatmojo, P., \& Nurhidayat, D. (2018). Pengembangan Aplikasi Android Untuk Pembelajaran 
3060 Pengembangan Media Pembelajaran Webtoon untuk Menanamkan Sikap Toleransi Siswa di Sekolah Dasar - Nuryanah, Linda Zakiah, Fahrurrozi, Uswatun Hasanah

DOI: https://doi.org/10.31004/basicedu.v5i5.1244

Pneumatik. Jurnal Pendidikan Vokasional Teknik Elektronika (Jvote), 1(1), 1-5. Https://Doi.Org/10.21009/Jvote.V1i1.6886

Siwi, M. K., Syofyan, R., \& Hayati, A. F. (2018). Pengembangan Webtoon Sebagai Media Pembelajaran Micro Teaching Di Fakultas Ekonomi Universitas Negeri Padang. Pakar Pendidikan, 16(1), 47-59.

Sugiyono. (2019). Metode Penelitian Pendidikan (3rd Ed.). Alfabeta CV.

Tafonao, T. (2018). Peranan Media Pembelajaran Dalam Meningkatkan Minat Belajar Mahasiswa. Jurnal Komunikasi Pendidikan, 2(2), 103. Https://Doi.Org/10.32585/Jkp.V2i2.113

Tim Wahid Foundation \& Lembaga Survei Indonesia. (2018). Laporan Survei Nasional Tren Toleransi Sosial-Keagamaan Di Kalangan Perempuan Muslim Indonesia.

Wahyu Nuning B, H. (2016). Pengembangan Komik Untuk Meningkatkan Motivasi Belajar Dan Keterampilan Membaca Pemahaman Siswa Kelas IV. Jurnal Prima Edukasi, 4 No. 2. 